\title{
Bioaccumulation of trace elements in the hard clam, Meretrix lyrata, reared downstream of a developing megacity, the Saigon-Dongnai River Estuary, Vietnam
}

Viet Tuan Tran \&Phuoc-Dan Nguyen \&Emilie Strady

\begin{abstract}
A large number of white hard clam farms are in the estuary shoreline of Saigon-Dongnai Rivers, which flow through Ho Chi Minh City, a megacity, and numerous industrial zones in the basin catchment area. In this study, eleven trace elements ( $\mathrm{Mn}, \mathrm{Fe}, \mathrm{Co}$, $\mathrm{Ni}, \mathrm{Cu}, \mathrm{Zn}, \mathrm{As}, \mathrm{Se}, \mathrm{Cd}, \mathrm{Hg}$, and $\mathrm{Pb}$ ) in the hard clam Meretrix lyrata and its habitats including surface water, suspended particulate matter, and sediment were evaluated to understand the bioaccumulation of trace metals
\end{abstract}

\footnotetext{
V. T. Tran

Vietnam Institute for Tropical Technology and Environmental Protection (VITTEP), 57A Truong Quoc Dung St., Phu Nhuan District, Ho Chi Minh City, Vietnam
}

V. T. Tran : P.<D. Nguyen ( *) : E. Strady Centre Asiatique de Recherche sur l'Eau (CARE), Ho Chi Minh City University of Technology (HCMUT), District 10, Ho Chi Minh City, Vietnam

e-mail: npdan@hcmut.edu.vn

P. D. Nguyen

Univ. Grenoble Alpes, CNRS, IRD, Grenoble INP, IGE,

F-38000 Grenoble, France

\section{E. Strady}

Vietnam National University Ho Chi Minh City (VNU-HCM),

Thu Duc District, Ho Chi Minh City, Vietnam

\section{E. Strady}

Aix-Marseille University, Mediterranean Institute of Oceanography (MIO), Université de Toulon, CNRS/IRD,

Marseille, France from the environment into the whole tissues of the hard clam as well as its different organs. The samples were collected monthly in dry, transition, and wet seasons of the southern part of Vietnam from March to September 2016. The results showed that seasonal and spatial variations of the studied metal concentrations in the hard clam $M$. lyrata might be influenced by the sea current as well as the surface runoff in the rainy season. The relationship between condition index and the element concentrations in $M$. lyrata might be affected by the living environment conditions and farming methods. In addition, the hazard index values of all trace elements in the hard clam $M$. lyrata harvested in the sampling time show that the hard clams farmed in the study area were safe for local consumers.

Keywords White hard clam · Trace metal Condition index $\cdot$ Biomonitoring $\cdot$ Human health risk

\section{Introduction}

Trace metals in aquatic environment originate from either natural processes or human activities. Natural sources are mostly from erosion, chemical rock weathering, volcanic activity, or soil leaching, whereas the anthropogenic sources are mainly from urban surface runoff and agricultural, industrial, and domestic activities. Trace metals are ubiquitous in aquatic environment, but their speciation is changing according to the physicochemical conditions of the environment, especially at the estuarine interface. One of the most 
serious problems associated with metals in the aquatic environment is their bioaccumulation in organisms, which can be toxic for the aquatic organisms themselves and can present a health risk for the humans who are consuming them (Sakellari et al. 2013; Tao et al. 2012).

The Bivalvia class has the capacity to accumulate trace metals in proportion to the environmental contamination levels (Baudrimont et al. 2005; Sakellari et al. 2013). The level of accumulation in biota (both the

whole organism and its specific organs) is calculated using the accumulation factors, which are defined as the ratio of the concentration of pollutants accumulated in

biota to the concentration of pollutants in the abiotic medium. For each environment media, a specific factor is used such as the bioaccumulation factor for the water, the biota-sediment accumulation factor for sediment (BSAF), and the biota-suspended particulate matter accumulation factor (BSPMAF) for suspended particles (Antunes et al. 2007; Belabed et al. 2013; Rzymski et al. 2014). The metal accumulation differed according to the organs and tissues of bivalves: some organs might be more sensitive and so might be a specific indicator for an environmental pollution rather than the whole body burdens (Tarique et al. 2012; Vodopivez et al. 2015).

Ho Chi Minh City (HCMC), the biggest economical city in Vietnam, has a high rate of urbanization and industrialization that has resulted in serious water issues such as heavy metals and nutrient contaminations, in the Saigon-Dongnai (SG-DN) Rivers (Tuyet et al. 2019; Strady et al. 2016; Vo 2007). Thanh-Nho et al. (2018) show that the metal concentrations in the estuary of the SG-DN Rivers could be changed due to the effects of surface runoff and soil leaching level in different seasons. At the mouth of the SG-DN Rivers, on the left bank (Can Gio District) and on the right bank (Tien Giang Province) are localized important commercial aqua-products of Asiatic hard clam Meretrix lyrata (G.B. Sowerby II, 1851). The area of clam farms at Can Gio was 800 ha, while it was 2000 ha at Tan Thanh (van Duijn et al. 2012). Normally, the hard clam farming period suitable for market provision is in the range from 12 to 18 months. Some previous studies focused on the effects of nutrients, temperature, salinity, rainwater quality, and tidal region on the $M$. lyrata hard clam growth (Son and Tung 2011) or genetic studies (Wu et al. 2014). A few studies focused on the accumulation and excretion of $\mathrm{Cd}$, As, and $\mathrm{Pb}$ (Pham 2007) and monitoring of the metal concentrations in hard clam species along the coastal of Vietnam (Le 2016; Tu et al. 2010; Phuong and Khoa 2013). However, these studies only evaluated a few of typical metals in short survey time or the sampled hard clams collected at the local markets. Hop et al. (2017) sampled hard clams farmed at Tan Thanh beach in the rainy season in 2015 and found a significant correlation between metal concentrations in the clams and the sediment fractions and safe limit for human consumption. Until now, the metal concentrations in specific organs of the M. lyrata hard clam as well as the correlation between metals in the hard clam farmed in the natural habitat and its physiological state have not been deeply studied in Vietnam. Therefore, this study aimed (i) to determine trace elements (Mn, Fe, Co, Ni, Cu, Zn, As, Se, Cd, Hg, and Pb) in $M$. lyrata and its living environment along the shoreline of the SG-DN River Estuary in the southern part of Vietnam from March to September 2016 that lasted from the late half of the dry season to the early midrainy season; (ii) to assess the spatial and seasonal variation of trace element concentrations in the hard clam $M$. lyrata and its habitats; and (iii) to estimate the health risks for the local consumers of the $M$. lyrata clam using the hazard quotient.

Materials and methods

Study area

The sampling sites are located in the southern part of Vietnam, at the mouth of the SG-DN River system, which is the third biggest river basin in Vietnam (Fig. 1). They are under the area of tropical monsoon climate, where the rainy and dry seasons last from May to November and from December to April next year, respectively. In the year 2016, the transition period, which was determined based on the variation of measured monthly rainfalls, lasted from May to July-those were months of the late dry season and the early rainy season (Supplement 1) (IMHEN 2018). Under the tropical monsoon climate, the strong northeast monsoon occurs from March to April and the southwest monsoon starts in May, becoming the strongest in August (IMHEN 2018; SRHC 2018). Similarly, the sea currents flow in the same direction with the monsoons (i.e., from the southwest to the northeast in the rainy season and vice versa in the dry seasons) (Fang et al. 2012). In addition, the studied area is affected by semi-irregular diurnal tide. 
The three following sites were selected in the study: (i) Can Thanh and (ii) Dong Hoa in Can Gio area, located on the northeast part of the mouth of the SGDN Rivers, and (iii) Tan Thanh located between the southwest part of the SG-DN estuary and the mouth of the Tien River, the northern branch of the Mekong Delta. The Meretrix lyrata hard clams are reared in the intertidal silty sand flat beaches and are harvested during ebb tide (Tong and Nguyen 2011). Only 12-24-monthold hard clam individuals, of which size is normally big enough to harvest to sell, were selected to study. The hard clams sampled at the Can Thanh site had been raised from the clam seeds with the age of less than 3 months, whereas the ones collected at Tan Thanh had been reared from the 3-6-month-old clam seeds and the ones collected at the Dong Hoa were drifted from the clam farms in the neighboring beaches.

\section{Sampling and handling}

At each sampling site, seawater, suspended particulate matters (SPM), sediment, and hard clam samples were collected once per month from March to September 2016. During high tide, $50 \mathrm{~mL}$ of seawater was filtered through a $0.2-\mu \mathrm{m}$ polytetrafluoroethylene (PTFE) filter paper (Omnipore ${ }^{\mathrm{TM}}$ ), acidified with a $0.05-\mathrm{mL} \mathrm{HNO}_{3}$ (65\%, Merck, Suprapur®), and stored in a polyethylene (PE) bottle at $4{ }^{\circ} \mathrm{C}$. SPM were collected by filtering 200 $\mathrm{mL}$ of seawater using a pre-weighted $0.45-\mu \mathrm{m}$ Whatman ${ }^{\circledR}$ filter paper. During low tide, sediment and hard clam were sampled. Sediment sample was a composite of five samples collected within an area of $5 \times 5$ $\mathrm{m}$. At each site, forty individuals of 12-24-month-old hard clam with shell length ranging from 26.6 to $42.6 \mathrm{~cm}$ were manually collected using the handy clam harvesting tools (Truong 2000). Then, they were stored in plastic bags, transported to the laboratory, and cleaned with tap water before preservation at $-20{ }^{\circ} \mathrm{C}$.

Sample preparation, digestion, and metal analysis

For each clam individual, the shell and soft body were separated and its soft body was dissected into three parts, the gill $(\mathrm{G})$, the digestive gland (DG), and the remaining tissues $(\mathrm{R})$, using a stainless steel knife. The condition index (CI), which represents the physiological state of the sampled hard clam, was determined by Eq. 1 (Markert et al. 2003):
CI $1 / 4 \frac{m_{\text {issue }}}{m_{\text {shell }}} 100$

where $m_{\text {tissue }}$ is the wet weight of the soft body (g) and $m_{\text {shell }}$ is the weight of the shell ( $\left.\mathrm{g}\right)$.

Each sample of whole body or dissected part was a composite of five individual clams, of which the total weight was big enough to analyze the metals. Then, the composite sample was dried using a freeze dryer (Alpha 1-2 LDplus Christ ${ }^{\circledR}$ ) for at least $24 \mathrm{~h}$ and ground homogeneously using a stone pestle and mortar and stored in a PE zip bag. A $200 \mathrm{mg}$ of the ground sample was added to a $5-\mathrm{mL} \mathrm{HNO}_{3}$ (65\%, Merck, Suprapur®) in a PTFE vial at $110^{\circ} \mathrm{C}$ for

$3.5 \mathrm{~h}$ on the hot plate (Strady et al. 2011). Subsequently, 4 $\mathrm{mL}$ of digested solution was mixed with $10 \mathrm{~mL}$ of the purified water $(\mathrm{Elga} \AA)$ and stored in a polypropylene (PP) tube at $4{ }^{\circ} \mathrm{C}$ before analysis. Eleven elements including $\mathrm{Mn}$, $\mathrm{Fe}, \mathrm{Co}, \mathrm{Ni}, \mathrm{Cu}, \mathrm{Zn}, \mathrm{As}, \mathrm{Se}, \mathrm{Cd}, \mathrm{Hg}$, and $\mathrm{Pb}$ were analyzed by the inductively coupled plasma mass spectrometry (ICPMS, Agilent 7700x series).

Sediment and SPM samples were dried in a freeze dryer (Alpha 1-2 LDplus Christ ${ }^{\circledR)}$ ) for at least $24 \mathrm{~h}$. Then, $100 \mathrm{mg}$ of homogeneous ground (i.e., using stone pestle and mortar) dried sediment and SPM samples were placed in PTFE vials and 2-mL $\mathrm{HNO}_{3}(65 \%$, Merck, Suprapur®) and 4-mL $\mathrm{HCl}(30 \%$, Merck, Suprapur®) were added to those vials (Sekabira et al. 2010). The vials were put in ultrasonic bath for $20 \mathrm{~min}$ before heating by a hot plate at $120{ }^{\circ} \mathrm{C}$ for $4 \mathrm{~h}$. The digested solution was then evaporated to dryness at 60 ${ }^{\circ} \mathrm{C}$ on the hot plate. Subsequently, $10 \mathrm{~mL}$ of purified water $\left(\right.$ Elga $\left.{ }^{\circledR}\right)$ and a $0.5-\mathrm{mL} \mathrm{HNO}_{3}(65 \%$, Merck, Suprapur $\left.{ }^{\circledR}\right)$ were added into the dried sample and the solution was kept at $65^{\circ} \mathrm{C}$ for $30 \mathrm{~min}$. Finally, $3.5 \mathrm{~mL}$ of the solution and a $6.5-\mathrm{mL}$ purified water $(\mathrm{Elga} \AA)$ were added into a PP tube and it was kept at $4{ }^{\circ} \mathrm{C}$ before analysis. Eleven elements including $\mathrm{Mn}, \mathrm{Fe}, \mathrm{Co}, \mathrm{Ni}, \mathrm{Cu}$, $\mathrm{Zn}$, As, $\mathrm{Se}, \mathrm{Cd}, \mathrm{Hg}$, and $\mathrm{Pb}$ were analyzed using the ICP-MS (Agilent 7700x series).

\section{Quality assurance and quality control}

The PTFE vials were cleaned, soaked in $10 \% \mathrm{HNO}_{3}$ at $80{ }^{\circ} \mathrm{C}$ for $24 \mathrm{~h}$, and then filled with $2 \% \mathrm{HNO}_{3}$ solution for storage. The other laboratory apparatuses including bottles, pestles, mortars, PP tubes and stainless steel knifes were cleaned and soaked in $10 \% \mathrm{HNO}_{3}$ for more than $24 \mathrm{~h}$, then rinsed with purified water $\left(\mathrm{Elga}^{\circledR}\right)$ at least three times, dried, and stored in a PE zip bag. 


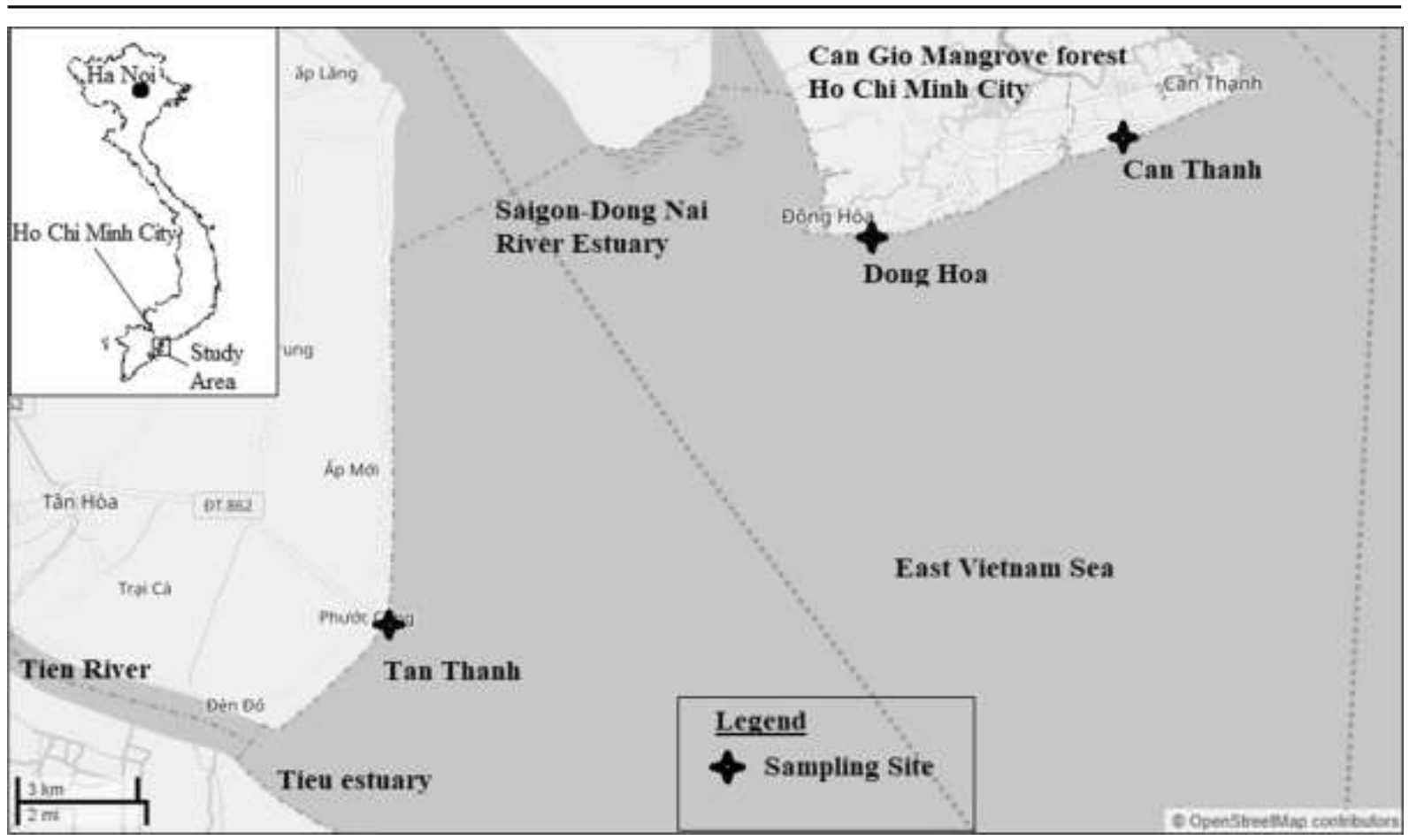

Fig. 1 Three sampling sites (Can Thanh, Dong Hoa, and Tan Thanh) near the estuary of the SG-DN River system

The certified material references (CRM) of the National Research Council Canada were used for trace metal analysis in the study including (i) MESS-3 as marine sediment CMR and (ii) TORT-3 which is a flesh of the lobster hepatopancreas as CMR of mollusk flesh. The recoveries of $\mathrm{Mn}, \mathrm{Fe}, \mathrm{Co}, \mathrm{Ni}, \mathrm{Cu}, \mathrm{Zn}, \mathrm{As}, \mathrm{Se}, \mathrm{Cd}$, $\mathrm{Hg}$, and $\mathrm{Pb}$ for MESS-3 were 101, 100, 90, 96, 96, 96, $99,93,100,107$, and $105 \%$, respectively, whereas those for TORT-3 were 94, 91, 98, 90, 95, 96, 106, 103, 95, 95 , and $93 \%$, respectively.

\section{Risk assessment}

The hazard quotient (HQ) in the study was used for the human health risk assessment of the local people consuming metal-contaminated hard clams. The HQ is calculated by Eq. 2 (U.S. EPA 2011):

$H Q^{1 / 4} \frac{E D I^{1 / 4}}{R f D} \frac{C_{\text {bivalve }} * E F^{*} E D^{*} \frac{d c_{\text {bivalve }}}{b w}}{R f D^{*} A T}$ ð2P

where $b w$ is the body weight $(\mathrm{kg})$. The average local body weight is $60 \mathrm{~kg}$ which is equivalent to the Asian body weight of $57.7 \mathrm{~kg}$ in 2005 (Walpole et al. 2012);
$E D I$ is the estimated daily intake $(\mu \mathrm{g} / \mathrm{kg}$ bw/day); $C_{\text {bivalve }}$ is the metal concentration in hard clam tissue $\left(\mu \mathrm{g} / \mathrm{g}\right.$ wet weight); $d c_{\text {bivalve }}$ is the daily bivalve consumption of $4.97 \mathrm{~g}$ bivalve/capita/day (FAOSTAT 2017); $E F$ is the exposure frequency, 350 days/year (U.S. EPA 2011); ED is the exposure duration, 30 years for adults (U.S. EPA 2011); $A T$ is the actual exposure time (AT $=365$ days/year $\times E D=19,950$ days $)$, $R f D$ is the reference dose interpreted as the tolerable daily intake ( $\mu \mathrm{g} / \mathrm{kg}$ of body weight/day). The values of $R f D$ is presented in Table 1 .

In general, HQ is used for risk assessment of a single contaminant that a human receptor is exposed via a single pathway like ingestion, while hazard index (HI) is the sum of HQ of contaminants in the mixture, which the receptor is exposed (U.S. EPA 2005). This method assumes that the potential risk concern is attributed to the additional effects of the contaminants and entry associated with each exposure pathway such as inhalation or ingestion does not directly consider. In this study, the health risk for human receptor being exposed to all metals available in the hard clam including $\mathrm{Mn}, \mathrm{Fe}, \mathrm{Co}$, $\mathrm{Ni}, \mathrm{Cu}, \mathrm{Zn}, \mathrm{As}, \mathrm{Se}, \mathrm{Cd}, \mathrm{Hg}$, and $\mathrm{Pb}$ was evaluated by using HI (Bilgin and Uluturhan-Suzer 2017) that is calculated by Eq. $\underline{3}$ : 
$H I 1 / 4 \sum H Q s$

where $\mathrm{HI}$ is the hazard index for a specific exposure pathway and HQs is the hazard quotient for chemicals of potential concerns or studied metals.

Metal bioaccumulation factors

The biota-suspended particulate matter accumulation factor (BSPMAF) and biota-sediment accumulation factor (BSAF) were calculated based on Eq. 5(Antunes et al. 2007):

BSPMAF $1 / 4 \frac{C_{\text {clam }}}{C_{S P M}}$ ð4

BSAF $1 / 4 \frac{C_{\text {Clam }}}{C_{\text {Sediment }}}$

where $C_{\text {clam }}$ is the metal concentration in $M$. lyrata or its organ ( $\mathrm{mg} / \mathrm{kg}$ dry weight) and $C_{S P M}(\mathrm{mg} / \mathrm{kg}$ dry weight) and $C_{\text {Sediment }}(\mathrm{mg} / \mathrm{kg}$ dry weight) are the metal concentrations in SPM and sediment, respectively.

Data analysis

The SPSS 16.0 and Microsoft Excel 2013 were used for data analysis in this study. They were used to calculate the mean values, standard deviation, analysis of variance (ANOVA), Pearson correlation, Tukey post hoc test, and other statistical indices.

Results and discussion

Seasonal trends of metal concentrations in M. lyrata and its habitats

Figure 2 illustrated that the mean metal concentrations in surface sediment samples were stable over the sampling period, while those in SPM and soft tissues of hard clams significantly fluctuated. Table $\underline{2}$ shows that the mean concentrations of $\mathrm{Co}, \mathrm{Ni}, \mathrm{Cu}, \mathrm{Zn}, \mathrm{Se}, \mathrm{Cd}$, and $\mathrm{Hg}$ in the total soft tissues of all hard clams were significantly different between seasons (ANOVA test results $p$-values < 0.05), with lower concentrations during the dry season (Tukey post hoc test, Supplement 2) and higher ones in May (Fig. 2). The mean concentrations of trace elements in SPM, except $\mathrm{Hg}$ and $\mathrm{Cd}$, also increased from March in the dry season to May in the transition period. Similarly, the total metal concentrations in the seawater (i.e., sum of particulate and dissolved metal concentrations, Supplement 3) were higher during the rainy season than those during the dry season. Thanh-Nho et al. (2018) claimed that the increase of rainfall in the SG-DN River basin in the transition time mobilized both dissolved and particulate metals $(\mathrm{Fe}, \mathrm{Cr}, \mathrm{Ni}$, and $\mathrm{Pb}$ ) from the terrestrial environment to the aquatic environment. This seasonal change of metal concentrations in the living habitat may lead to the different exposures of clams to metals. The result was similar to that of George et al. (2013), who observed higher metal ( $\mathrm{Fe}, \mathrm{Co}, \mathrm{Ni}, \mathrm{Cu}, \mathrm{Zn}, \mathrm{Cd}$, and $\mathrm{Pb}$ ) concentrations in the black clam Villorita cyprinoides during the pre-monsoon period than those in the dry season in India.

The metal concentrations in clams, especially in the gills, digestive glands, and in the remaining tissues, varied with seasons. Indeed, Table 2 presented that the metal concentrations significantly increased from the dry to wet seasons (ANOVA test, $p$-values $<0.05$ except $\mathrm{Pb}$ in G-DG-R; As in R; Se in G; Hg in DG-R), and the peak concentrations in all organs were obtained during the transition time (Fig. $\underline{3}$ ). The increase of both dissolved and particulate metal concentrations seems to affect both the gills and the digestive glands and subsequently the remaining tissues. The sediment bioaccumulation factors (BSAF) and the suspended particulate one (BSPMAF) for all metals did not vary between seasons (Supplement 4), except BSPMAF for Ni and BSAF for $\mathrm{Ni}, \mathrm{Co}$, and $\mathrm{Hg}$. The absence of seasonal variation in the bioaccumulation factors claimed that the seasonal variation of metals in clams reflects the metal bioavailability in the suspended particulates and the sediment.

Rzymski et al. (2014) addressed that metal bioaccumulation in the species happened from the environmental compartments as the value of the bioaccumulation factor is greater than 1 . The BSAF and BSPMAF for each studied metal were determined in three seasons (Supplement 4). The values of BSAF for $\mathrm{Mn}, \mathrm{Fe}, \mathrm{Co}$, and $\mathrm{Pb}$ and $\mathrm{BSPMAF}$ of $\mathrm{Mn}, \mathrm{Fe}, \mathrm{Co}, \mathrm{Ni}, \mathrm{Cu}, \mathrm{Zn}, \mathrm{As}, \mathrm{Se}$, and $\mathrm{Pb}$ were less than 1 , and thus those metals might not accumulate in $M$. lyrata via the pathways of sediment and SPM. The values of BSAF for $\mathrm{Cd}, \mathrm{Cu}, \mathrm{Zn}, \mathrm{As}$, and $\mathrm{Se}$ and BSPMAF for $\mathrm{Cd}$ higher than 1 in all three seasons indicated that the bioaccumulation of $\mathrm{Cd}, \mathrm{Cu}$, 


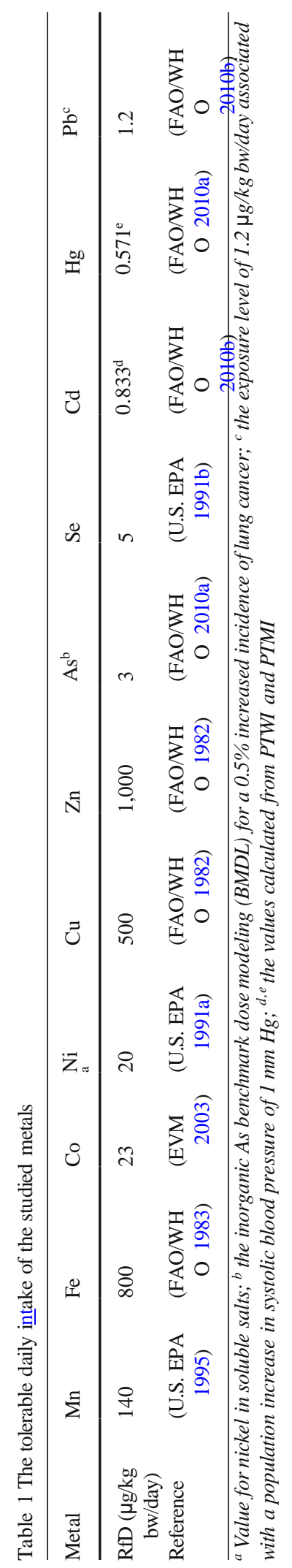

Zn, As, and Se by sediment and Cd by SPM clearly happens in the hard clam M. lyrata. The values of BSAF for $\mathrm{Ni}$ in both transition and wet seasons and $\mathrm{Hg}$ in only the wet season were higher than 1. Those BSAF and BSPMAF show the effects of the above metals from the solid-phase compartments on bioaccumulation.

Spatial metal concentration variation in $M$. lyrata and its habitats

Spatially, significant differences of $\mathrm{Co}, \mathrm{Ni}, \mathrm{Zn}, \mathrm{Se}$, $\mathrm{Cd}$, and $\mathrm{Hg}$ concentrations in the soft tissues of clams collected at the three sampling sites were measured (ANOVA test, $p<0.05$ ). The higher concentrations were observed at the Tan Thanh site based on the result of the Tukey post hoc test (Supplement 5). Note that trace metals in the liv- ing habitats may accumulate into the bivalves ( $\mathrm{Wu}$ et al. 2013); therefore, the higher metal accumula- tion in the clams at Tan Thanh may have a sig- nificant correlation to the higher metal contents of the sediment and SPM (Supplements 6 and 7).

The concentrations of $\mathrm{Mn}, \mathrm{Fe}, \mathrm{Co}, \mathrm{Ni}, \mathrm{Cu}, \mathrm{Zn}, \mathrm{Se}$, $\mathrm{Cd}, \mathrm{Hg}$, and $\mathrm{Pb}$ in the clams were lower in the dry season at both the Can Thanh and Dong Hoa sites in Can Gio District, while at Tan Thanh in Tien Giang Province, the concentrations of $\mathrm{Mn}, \mathrm{Fe}, \mathrm{Cu}, \mathrm{As}, \mathrm{Se}, \mathrm{Hg}$, and $\mathrm{Pb}$ in the dry season were higher in comparison with those in the transition and wet seasons (Fig. 4). Those opposite seasonal changes of some trace metal concentrations in M. lyrata between the Tan Thanh site and sites in Can Gio District might be caused by the effect of coastal current around the SG-DN River Estuary. During the dry season, the sea current flows from the North to the South and during the rainy season it flows from the South to the North (Fang et al. 2012). Lower total metal concentrations were found in seawater (Supplement 3) and in M. lyrata (except As) at sites in Can Gio District in comparison with those at Tan Thanh during the dry season. The seasonal change of sea current influences on the SPM concentration at the Tan Thanh site, where more SPM concentrations come from the Tien River, a branch of the Mekong Delta (Marchesiello et al. 2019). Consequently, the change of SPM concentrations could affect the total metal concentrations (i.e., particulate and dissolved metals) in seawater (Strady et al. 2017; Thanh-Nho et al. 2018), and thus it may result in the potential exposure of clams to metals available in SPMs. 


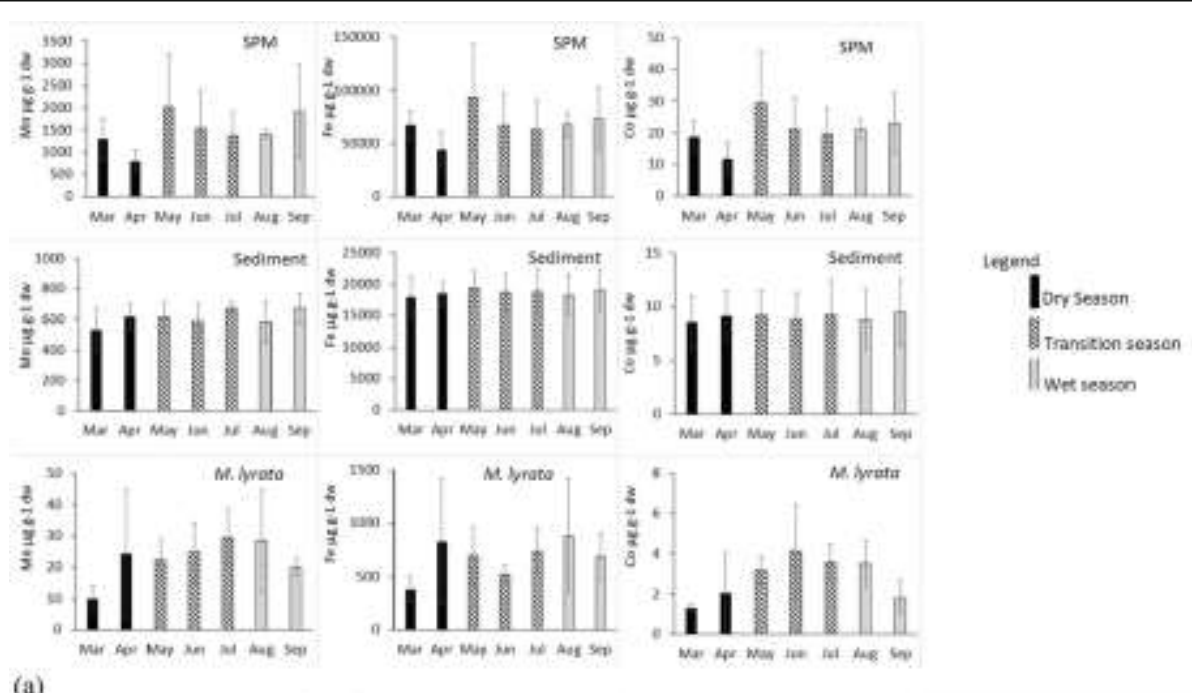

(a)
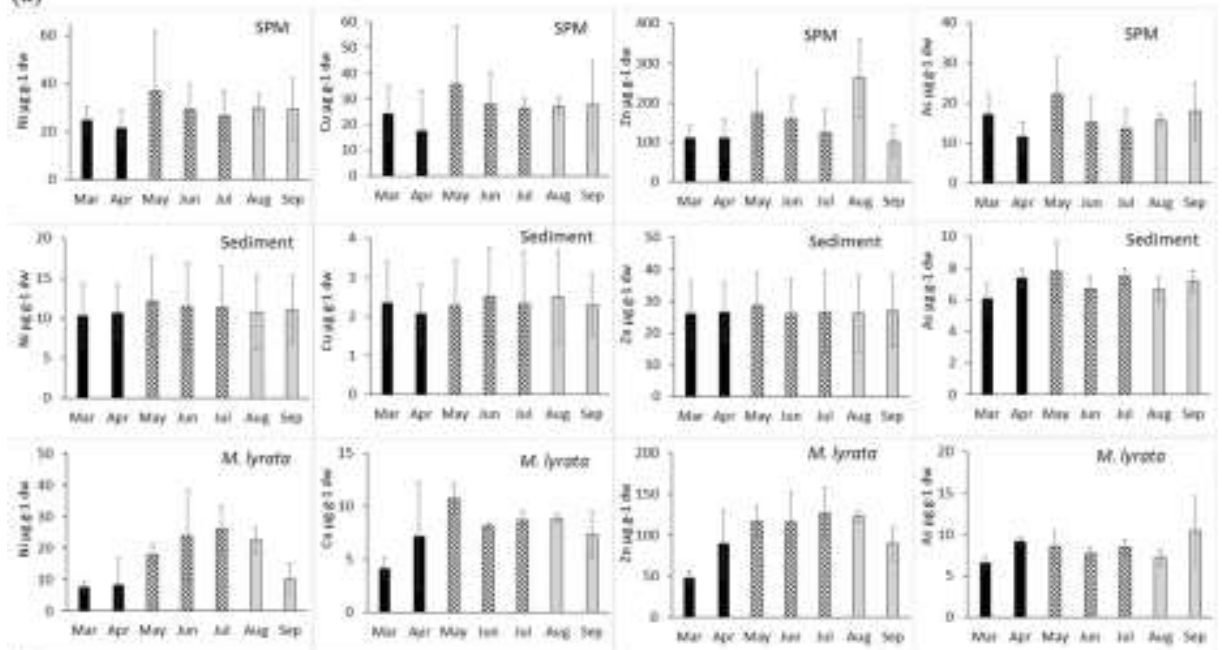

(b)
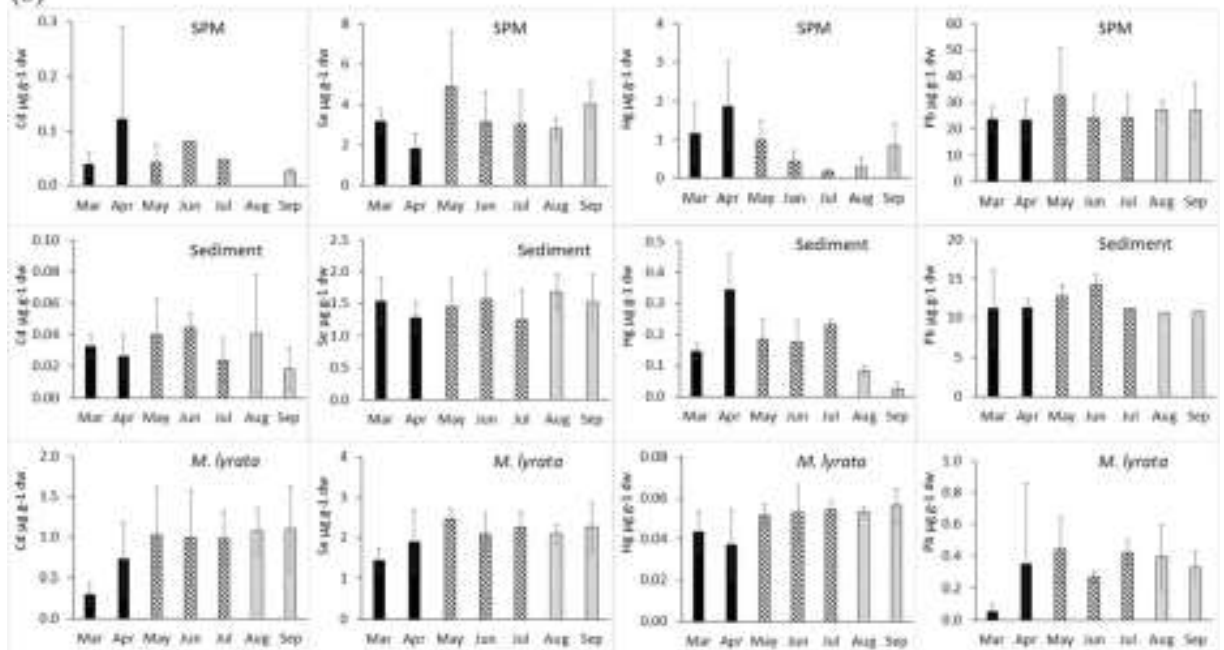

(c)

Fig. 2 Mean metal concentrations (Mn, Fe, Co (part a); Ni, Cu, Zn, As, (part b); and Se, Cd, Hg, Pb (part c)) in SPM, sediment, and M. lyrata during the dry season, the transition season, and the wet season at all sampling sites 
Table 2 The seasonal differences of element concentrations in the hard clam $M$. lyrata based on ANOVA test results

\begin{tabular}{lllll}
\hline Element & \multicolumn{2}{l}{$p$-value (Sig.) } & & \\
\cline { 2 - 5 } & Whole body & Gill & Digestive gland & Remainder \\
\hline $\mathrm{Mn}$ & 0.338 & $0.000^{*}$ & 0.371 & $0.012^{*}$ \\
$\mathrm{Fe}$ & 0.318 & $0.002^{*}$ & $0.029^{*}$ & $0.026^{*}$ \\
$\mathrm{Co}$ & $0.000^{*}$ & $0.001^{*}$ & $0.000^{*}$ & $0.000^{*}$ \\
$\mathrm{Ni}$ & $0.000^{*}$ & $0.000^{*}$ & $0.000^{*}$ & $0.000^{*}$ \\
$\mathrm{Cu}$ & $0.000^{*}$ & $0.000^{*}$ & $0.000^{*}$ & $0.003^{*}$ \\
$\mathrm{Zn}$ & $0.000^{*}$ & $0.000^{*}$ & $0.000^{*}$ & $0.001^{*}$ \\
$\mathrm{As}$ & 0.744 & $0.012^{*}$ & $0.007^{*}$ & 0.140 \\
$\mathrm{Se}$ & $0.001^{*}$ & 0.704 & $0.008^{*}$ & $0.033^{*}$ \\
$\mathrm{Cd}$ & $0.000^{*}$ & $0.000^{*}$ & $0.000^{*}$ & $0.000^{*}$ \\
$\mathrm{Hg}$ & $0.002^{*}$ & $0.000^{*}$ & 0.393 & 0.474 \\
$\mathrm{~Pb}$ & 0.395 & 0.660 & 0.913 & $0.011^{*}$ \\
\hline
\end{tabular}

*Statistically significant difference with p-value $<0.05$

The condition index of organism is very sensitive to the pollutant levels and nutrient concentrations in its living habitat (Rainer and Mann 1992). Therefore, it is claimed that the different environment conditions and hard clam farming methods may influence the relationship between the $\mathrm{CI}$ and metal concentrations. CI values presented significant negative correlations with mean $\mathrm{Mn}, \mathrm{Fe}, \mathrm{Co}, \mathrm{Ni}, \mathrm{Cu}, \mathrm{Zn}, \mathrm{Se}, \mathrm{Cd}$, and $\mathrm{Pb}$ concentrations in the whole body of M. lyrata at the three sampling sites (Supplement 8). It means that the worse the physiological state of the hard clam, the higher metal concentrations in it were found. Similarly, the negative correlations were observed between $\mathrm{CI}$ and $\mathrm{Hg}, \mathrm{Cd}, \mathrm{Cu}, \mathrm{Ag}$, $\mathrm{Zn}$, and $\mathrm{Pb}$ in Mytilus edulis (Borchardt et al. 1988) and $\mathrm{Zn}$, $\mathrm{As}, \mathrm{Cd}, \mathrm{Pb}, \mathrm{Hg}, \mathrm{Cu}, \mathrm{Ni}$, and $\mathrm{Cr}$ in Mytilus galloprovincialis from the Mediterranean Sea (Andral et al. 2004). The CI values negatively correlated with the concentrations of $\mathrm{Mn}, \mathrm{Fe}, \mathrm{Co}, \mathrm{Ni}, \mathrm{Cu}, \mathrm{Zn}$, and $\mathrm{Pb}$ at the Can Thanh site; Co, Ni, Zn, Cd, and Hg at Tan Thanh; and $\mathrm{Fe}, \mathrm{Cd}$, and $\mathrm{Pb}$ at Dong Hoa (Supplement 8). As mentioned, the hard clams at the Can Thanh site are raised from juvenile until adult clams (12-18 months old), so that the CI of adult hard clam reflects the quality of their living environment. At the Tan Thanh site, the 3-6-month-old hard clams are brought from other farms and then they are raised to the 12- month-old ones. Therefore, the number of trace elements having a correlation with $\mathrm{CI}$ at the Tan Thanh site was less than that at the Can Thanh site. The similar situation was observed at Dong Hoa, the CI values only correlated with the concentrations of minor number of elements because those hard clams collected at Dong Hoa might not grow on-site.

The results of statistical analysis (in Supplement 9) show that the correlations between the metal concentrations in the whole tissues of $M$. lyrata and its living environmental components including SPM, sediment, and surface water have been only found for a few trace elements. In the previous studies, Dan et al. (2014) and Hop et al. (2017) observed the same situation at the Tan Thanh site. Some other studies investigated the nonsignificant statistical correlation between the metal concentrations in bivalve species and in their living environment (de Astudillo et al. 2005; Madkour et al. 2011; Salahshur et al. 2012). Madkour et al. (2011) presented that heavy metal accumulation in hard clams might not come directly from one source such as sediment but it could derive from other sources such as SPM or surface water. Therefore, some authors studied on correlations between metal concentrations in not only whole body tissue of bivalve species but also in their specific organs and their living environment such as sediment or even the specific fractions of sediment (Wong et al. 2016; Yap et al. 2014). In this study, the significant statistical correlations were found between $\mathrm{Cu}$ and $\mathrm{Zn}$ concentrations in SPM and the gill, Se in SPM and the digestion gland, and Ni and Co in SPM and both the gill and digestion gland of $M$. lyrata. The particulate metals mostly derive from the terrestrial environment (ThanhNho et al. 2018), and thereby the element concentrations in SPM might depend on the contamination of topsoil as well as the runoff surface in the river basin.

\section{Risk assessment of hard clam consumption}

Table $\underline{3}$ illustrated that the estimated hazard quotient (HQ) and the hazard index (HI) in this research were all less than the value of 1 , which indicates that the hard clams farmed in the study area were safe for consumers in terms of the studied metals as chemicals of potential concern. The similar observation was found in the study of (P. C. T. Nguyen et al. 2010). The HQs of total As at all three sampling sites were the highest in comparison with those of other metals. The fact that is that only inorganic As may adversely impact on the human health (Ratnaike 2003), whereas this study focused on total As concentration. Even though the HQs of $\mathrm{Cd}$ were smaller 


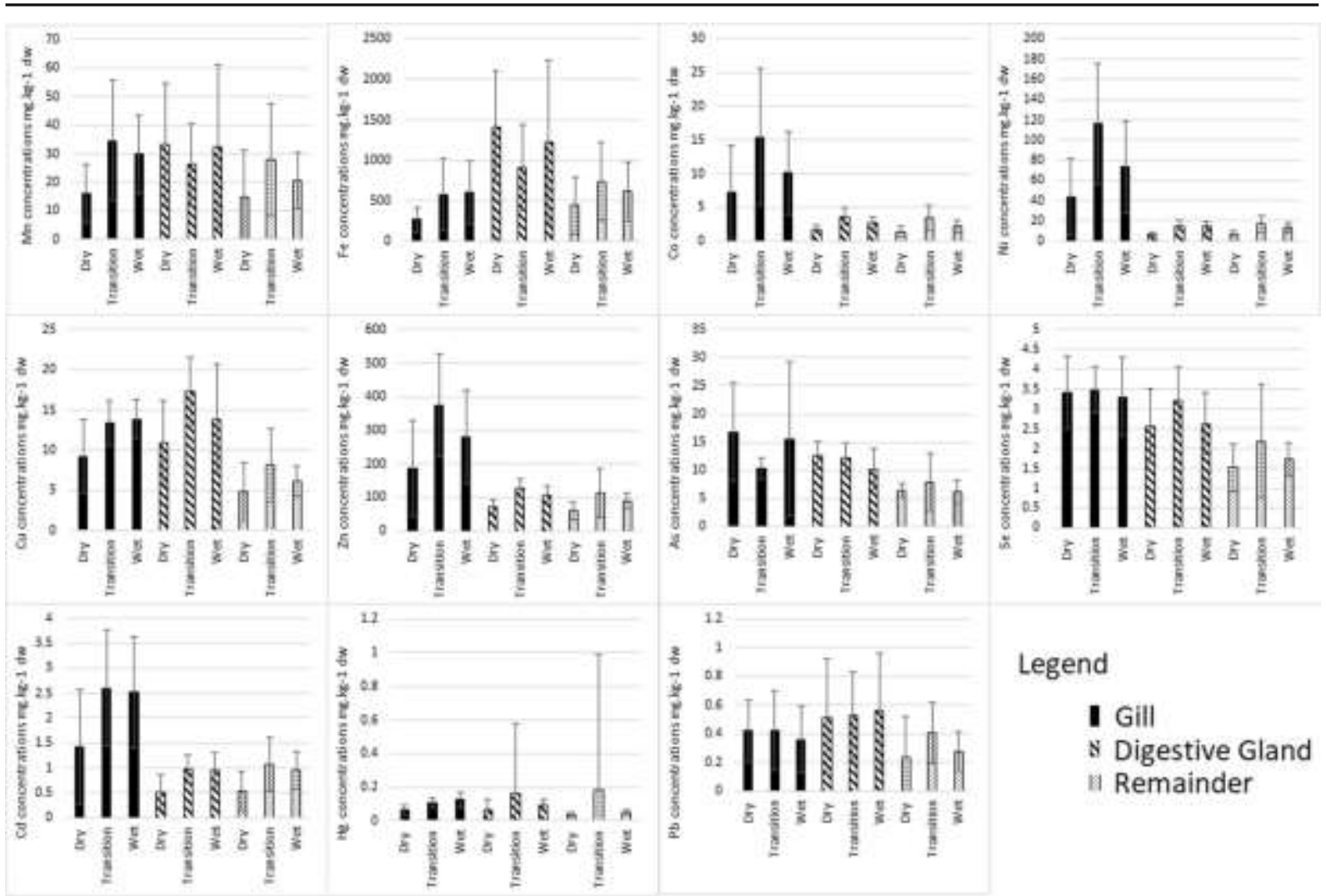

Fig. 3 Seasonal mean metal concentrations in various organs of the hard clam Meretrix lyrata

than those of As, the BSAF and BSPMAF values of $\mathrm{Cd}$ were the highest. This pointed out that $\mathrm{Cd}$ is an element which should be considered as a priority parameter to assess health risk and food safety for human consumption of hard clams farmed in the shoreline of the SG-DN River Estuary.
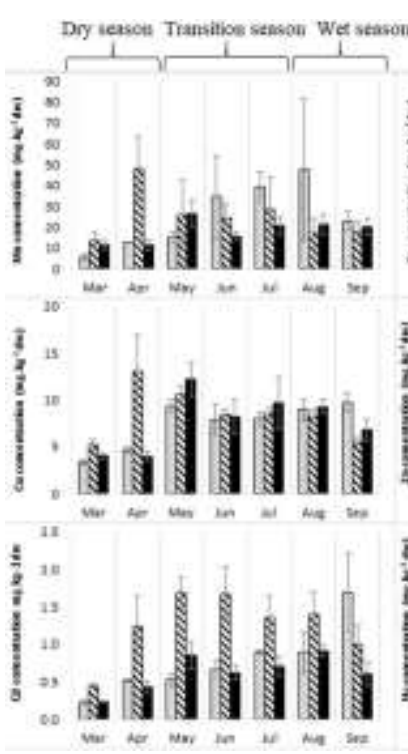
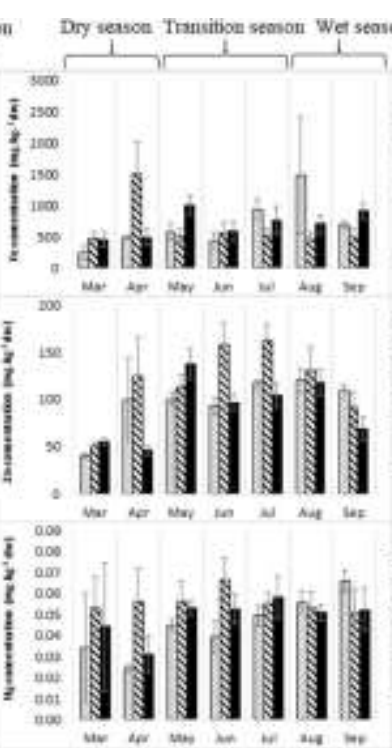

Dry seasce Trusition season Wet wonon
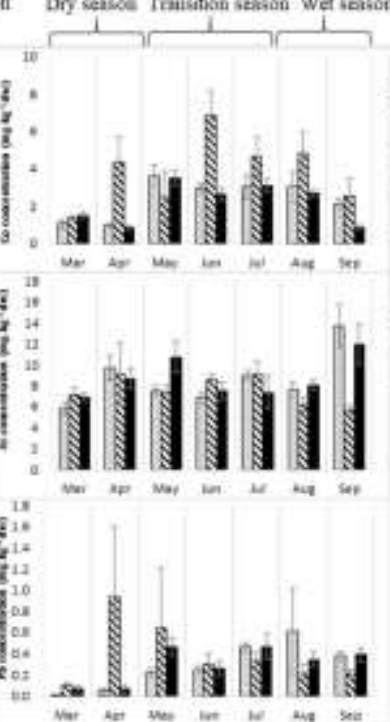

Dry betwon Tnesifion seasen Wer seasce
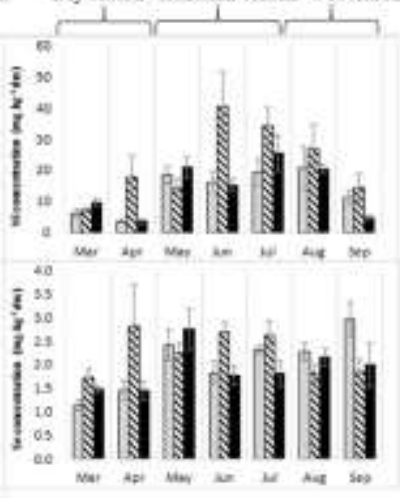

Legend

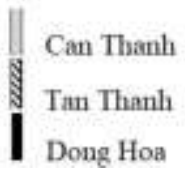

Fig. 4 Mean metal concentrations in M. lyrata at the Can Thanh, Tan Thanh, and Dong Hoa sites in 2016 
Table 3 The HQs and HIs of trace elements for the local consumer of the hard clam M. lyrata

\begin{tabular}{|c|c|c|c|c|c|c|c|c|c|c|c|c|}
\hline \multirow[t]{2}{*}{ Site } & \multicolumn{11}{|l|}{ HQ } & \multirow[t]{2}{*}{$\mathrm{HI}$} \\
\hline & Mn & $\mathrm{Fe}$ & $\mathrm{Co}$ & $\mathrm{Ni}$ & $\mathrm{Cu}$ & $\mathrm{Zn}$ & As & $\mathrm{Se}$ & $\mathrm{Cd}$ & $\mathrm{Hg}$ & $\mathrm{Pb}$ & \\
\hline Can Thanh & 0.0026 & 0.0130 & 0.0015 & 0.0097 & 0.0002 & 0.0014 & 0.0418 & 0.0059 & 0.0134 & 0.0012 & 0.0034 & $\begin{array}{l}0.09 \\
4\end{array}$ \\
\hline Dong Hoa & 0.0018 & 0.0119 & 0.0013 & 0.0100 & 0.0002 & 0.0013 & 0.0403 & 0.0053 & 0.0106 & 0.0012 & 0.0033 & 0.087 \\
\hline Tan Thanh & 0.0027 & 0.0120 & 0.0025 & 0.0162 & 0.0003 & 0.0017 & 0.0363 & 0.0065 & 0.0224 & 0.0014 & 0.0050 & $\begin{array}{l}0.10 \\
7\end{array}$ \\
\hline
\end{tabular}

Although the HQ of $\mathrm{Hg}$ was low, the BSAF and BSPMAF values of $\mathrm{Hg}$ ranged widely. It meant that a few of BSAF and BSPMAF values for $\mathrm{Hg}$ were greater than 1 . Mercury is one of the strong toxic elements; its presence in $M$. lyrata should be paid attention. Burger et al. (2012) and Olmedo et al. (2013) suggested that Se might protect the organisms from $\mathrm{Hg}$ toxicity. Therefore, the $\mathrm{Hg} / \mathrm{Se}$ molar ratio has been used for $\mathrm{Hg}$ toxicity risk assessment. In the case that the ratio is less than 1, an excess of Se concentration in hard clams might protect against $\mathrm{Hg}$ toxicity. In this study, the $\mathrm{Hg} / \mathrm{Se}$ molar ratio in the hard clam samples ranged between 0.0065 and 0.0374 . This result indicated that Se may moderate $\mathrm{Hg}$ toxicity in $M$. lyrata.

\section{Conclusions}

This study showed that the concentrations of studied elements in $M$. lyrata were much dependent on the seasonal and spatial variations. The changes of sea current and precipitation (surface runoff) might be the main effects on the metal concentrations in the hard clams and its living habitats. Based on the obtained results, it is suggested that the hard clam $M$. lyrata should have not been harvested in the transition time due to the high metal concentrations in hard clam tissues. The significant correlations between concentrations of studied trace elements and the physiological state of $M$. lyrata addressed that the CI can be used for prediction of the contamination level of some trace metals in these hard clams. Finally, the obtained HQ and $\mathrm{HI}$ values presented a low toxicological risk of trace elements for local consumers and it is claimed that the hard clam M. lyrata farmed in all sampling sites is safe for consumption when they are harvested during the study time (March to September 2016).
Acknowledgments Authors appreciate the financial supports by the UNU \& GIST Joint Program from the Gwangju Institute of Science and Technology and VNU-HCM under Grant No. B201620-05. The authors also thank the research assistants from the laboratories of CARE, VITTEP, and Faculty of Environment and Natural Resources for the analysis and sampling.

Author contributions We highly appreciate the submission guidelines of EMA Journal and we have no comments for that. However, we would be happy to send EMA Journal our suggestion in the future if we have any.

Funding information The major financial support is given by the UNU \& GIST Joint Program from the Gwangju Institute of Science and Technology and VNU-HCM under Grant No. B201620-05.

Data availability All measurement and analysis data in this manuscript have been conducted by the authors and they could be published without any conflict.

Compliance with ethical standards

Conflict of interest This manuscript presents the original research from the authors. So far, it has been submitted to only EMA Journal for publication.

Code availability Not applicable.

\section{References}

Andral, B., Stanisiere, J. Y., Sauzade, D., Damier, E., Thebault, H., Galgani, F., \& Boissery, P. (2004). Monitoring chemical contamination levels in the Mediterranean based on the use of mussel caging. Marine Pollution Bulletin, 49(9-10), 704712. https://doi.org/10.1016/j.marpolbul.2004.05.008.

Antunes, P., Gil, O., \& Reis-Henriques, M. A. (2007). Evidence for higher biomagnification factors of lower chlorinated PCBs in cultivated seabass. Sci Total Environ, 377(1), 3644. https://doi.org/10.1016/j.scitotenv.2007.01.094.

Baudrimont, M., Schäfer, J., Marie, V., Maury-Brachet, R., Bossy, C., Boudou, A., \& Blanc, G. (2005). Geochemical survey and metal bioaccumulation of three bivalve species 
(Crassostrea gigas, Cerastoderma edule and Ruditapes philippinarum) in the Nord Médoc salt marshes (Gironde Estuary, France). Science of the Total Environment, 337(13), $265-280$. http s://d o i.o rg/10.1016/j. scitotenv.2004.07.009.

Belabed, B. E., Laffray, X., Dhib, A., Fertouna-Belakhal, M., Turki, S., \& Aleya, L. (2013). Factors contributing to heavy metal accumulation in sediments and in the intertidal mussel Perna perna in the Gulf of Annaba (Algeria). Marine Pollution Bulletin, 74(1), 477-489. https://doi.org/10.1016 j.marpolbul.2013.06.004.

Bilgin, M., \& Uluturhan-Suzer, E. (2017). Assessment of trace metal concentrations and human health risk in clam (Tapes decussatus) and mussel (Mytilus galloprovincialis) from the Homa Lagoon (Eastern Aegean Sea). Environmental Science and Pollution Research, 24(4), 4174-4184. https://doi. org/10.1007/s11356-016-8163-2.

Borchardt, T., Burchert, S., Hablizel, H., Karbe, L., \& Zeitner, R. (1988). Trace metal concentrations in mussels: comparison between estuarine, coastal and offshore regions in the southeastern North Sea from 1983 to 1986. Marine Ecology Progress Series, 42, 17-31. https://doi.org/10.3354 Imeps042017.

Burger, J., Gochfeld, M., Jeitner, C., Donio, M., \& Pittfield, T. (2012). Interspecific and intraspecific variation in selenium: mercury molar ratios in saltwater fish from the Aleutians: potential protection on mercury toxicity by selenium. Science of the Total Environment, 431, 46-56. https://doi. org/10.1016/j.scitotenv.2012.05.024.

Dan, N. P., Hanh, D.V.B., V B. H., Nguyen, H. V., Lai, D. P., Trinh, B. H., Han, S., \& Hong, Y. (2014). Trace metals $(\mathrm{Cu}, \mathrm{Zn}, \mathrm{Pb}$ and $\mathrm{Cr})$ in Mollusca, sediment and water at Tien River Estuary-Mekong Delta in Viet Nam. In The 12th annual UNU \& GIST Joint Programme Symposium: Issues on Environmental multiPollutants. Da Nang, Viet Nam.

de Astudillo, L. R., Yen, I. C., \& Bekele, I. (2005). Heavy metals in sediments, mussels and oysters from Trinidad and Venezuela. International Journal of Tropical Biology, 53(1), 41-53.

Expert Group on Vitamins and Minerals. (2003). Safe upper levels for vitamins and minerals. Food standards Agency. https://cot.food.gov.uk/sites/default/files/vitmin2003.pdf

Fang, G., Wang, G., Fang, Y., \& Fang, W. (2012). A review on the South China Sea western boundary current. Acta Oceanologica Sinica, 31(5), 1-10. https://doi.org/10.1007 ls13131-012-0231-y.

FAO/WHO (1982). Twenty-Sixth Report of the Joint FAO/WHO Expert Committee on Food Additives (JECFA). Geneva.

FAO/WHO (1983). Twenty-Seventh Report of the Joint FAO/ WHO Expert Committee on Food Additives (JECFA). Geneva.

FAO/WHO (2010a). Summary and conclusions of the 72nd Meeting of the Joint FAO/WHO Expert Committee on Food Addit $i$ ves (JECFA). http://www.who. int/entity/foodsafety/chem/summary 72 rev.pdf

FAO/WHO (2010b). Summary and conclusions of the 73rd Meeting of the Joint FAO/WHO Expert Committee on Food Additives (JECFA). Geneva. http://www.fao.org/3/a-at862e. pdf
FAOSTAT (2017). Food supply - livestock and fish primary equivalent. FAO. http://www.fao.org/faostat/en/\#data/CL. Accessed 3 May 2017

George, R., Martin, G. D., Nair, S. M., \& Chandramohanakumar, N. (2013). Biomonitoring of trace metal pollution using the bivalve molluscs, Villorita cyprinoides, from the Cochin backwaters. Environmental Monitoring and Assessment, 185(12), 10317-10331. https://doi.org/10.1007/s10661013-3334-9.

Hop, N. V., Dieu, H. T., \& Phong, N. H. (2017). Metal speciation in sediment and bioaccumulation in Meretrix lyrata in the Tien Estuary in Vietnam. Environmental Monitoring and Assessment, 189, 189-299. https://doi.org/10.1007/s10661017-5995-2.

IMHEN (2018). Weather and climate information. VIET NAM INSTITUTE OF METEOROLOGY, HYDROLOGY AND CLIMATE CHANGE. http://imh.ac.vn/nghiep-vu/cat50 /Thong-bao-va-du-bao-khi-hau. Accessed 16 November 2019

Le, X. S. (2016). Determination of mercury accumulation factor in hard clam (Meretrix lyrata) at Bach Dang Estuary, Viet Nam. Environment and Natural Resources Research, 6(3), 18. https://doi.org/10.5539/enrr.v6n3p18.

Madkour, H. A., Obirikorang, K. A., Amisah, S., Otchere, F. A., \& Adjei-Boateng, D. (2011). Relationship between heavy metal concentrations in bottom sediments and the clam, Galatea paradoxa (Born 1778) from the Volta Estuary, Ghana. Journal of Environmental Protection, 02(06), 720-728. https://doi.org/10.4236/jep.2011.26083.

Marchesiello, P., Nguyen, N. M., Gratiot, N., Loisel, H., Anthony, E. J., Dinh, C. S., Nguyen, T., Almar, R., \& Kestenare, E. (2019). Erosion of the coastal Mekong Delta: assessing natural against man induced processes. Continental Shelf Research, 181, 72-89. https://doi.org/10.1016/j. csr.2019.05.004.

Markert, B. A., Breure, A. M., \& Zechmeister, H. G. (2003). Bioindicators and biomonitors: principles, concepts and applications. (J. O. Nriagu, Ed.). The Netherlands: Elsevier science.

Nguyen, P. C. T., Nguyen, N. H., Agusa, T., Ikemoto, T., Bui, C. T., Tanabe, S., \& Takeuchi, I. (2010). Concentrations of trace elements in Meretrix spp. (Mollusca: Bivalva) along the coasts of Vietnam. Fisheries Science, 76(4), 677-686. https://doi.org/10.1007/s12562-010-0251-5.

Olmedo, P., Hernández, A. F., Pla, A., Femia, P., Navas-Acien, A., \& Gil, F. (2013). Determination of essential elements (copper, manganese, selenium and zinc) in fish and shellfish samples. Risk and nutritional assessment and mercuryselenium balance. Food and Chemical Toxicology, 62, 299-307. https://doi.org/10.1016/j.fct.2013.08.076.

Pham, K. P. (2007). The accumulation and excretion of heavy metals $(\mathrm{Cd}, \mathrm{As}, \mathrm{Pb})$ in clam Meretrix lyrata and the change of those metals compounds in the hard clam body. Ho Chi Minh City University of Sciences.

Phuong, N. T. K., \& Khoa, N. C. (2013). Evaluation of heavy metals in tissue of shellfish from Can Gio coastline in Ho Chi Minh City, Vietnam. Asian Journal of Chemistry, 25(15), 8552-8556. https://doi.org/10.14233/ajchem.2013.14838.

Rainer, J. S., \& Mann, R. (1992). A comparison of methods for calculating condition index in eastern oyster, Crasostrea 
virginica (Gmeilin, 1791). Journal of Shellfish Research, 11(1), 55-58 J_Shell_Res_11_55_58.pdf.

Ratnaike, R. N. (2003). Acute and chronic arsenic toxicity. Postgraduate Medical Journal, 79, 391-396. https://doi. org/10.1136/pmj.79.933.391.

Rzymski, P., Niedzielski, P., Klimaszyk, P., \& Poniedziałek, B. (2014). Bioaccumulation of selected metals in bivalves (Unionidae) and Phragmites australis inhabiting a municipal water reservoir. Environmental Monitoring and Assessment, 186(5), 3199-3212. https://doi.org/10.1007/s10661-0133610-8.

Sakellari, A., Karavoltsos, S., Theodorou, D., Dassenakis, M., \& Scoullos, M. (2013). Bioaccumulation of metals (Cd, Cu, Zn) by the marine bivalves M. galloprovincialis, P. radiata, V. verrucosa and $\mathrm{C}$. chione in Mediterranean coastal microenvironments: association with metal bioavailability. Environmental Monitoring and Assessment, 185(4), 33833395. https://doi.org/10.1007/s10661-012-2799-2.

Salahshur, S., Bakhtiari, A. R., \& Kochanian, P. (2012). Use of Solen brevis as a biomonitor for $\mathrm{Cd}, \mathrm{Pb}$ and $\mathrm{Zn}$ on the intertidal zones of Bushehr-Persian Gulf, Iran. Bulletin of Environmental Contamination and Toxicology, 88(6), 951955. https://doi.org/10.1007/s00128-012-0599-6.

Sekabira, K., Origa, H. O., Basamba, T. A., Mutumba, G., \& Kakudidi, E. (2010). Assessment of heavy metal pollution in the urban stream sediments and its tributaries. International journal of Environmental Science and Technology, 7(3), 435-446.

Son, T.P.H., \& Tung, N.T. (2011). The relationship between natural conditions and the formation and development of clam grounds (Meretrix lyrata) in the Mekong Delta. In M. A. Stewart \& P. A. Coclanis (Eds.), Environmental Change and Agricultural Sustainability in the Mekong Delta (Vol. 45, pp. 303-333). Springer Netherlands. https://doi. org/10.1007/978-94-007-0934-8_18

SRHC (2018). Hydrometeorological Information. Southern Regional Hydrometeorological Center. http://www.kttv-nb. org.vn. (in Vietnamese). Accessed 16 Nov 2018

Strady, E., Blanc, G., Baudrimont, M., Schäfer, J., Robert, S., \& Lafon, V. (2011). Roles of regional hydrody- namic and trophic contamination in cadmium bioaccu- mulation by Pacific oysters in the Marennes-Oléron Bay (France). Chemosphere, 84(1), 80-90. org/10.1016/j.chemosphere.2011.02.051.

Strady, E., Dang, V. B. H., Némery, J., Guédron, S., Dinh, Q. T., Denis, H., \& Nguyen, P. D. (2016). Baseline seasonal investigation of nutrients and trace metals in surface waters and sediments along the Saigon River basin impacted by the megacity of Ho Chi Minh (Vietnam). Environmental Science and Pollution Research, 24(4), 3226-3243. https://doi.org/10.1007/s11356-016-7660-7.

Strady, E., Dinh, Q. T., Némery, J., Nguyen, T. N., Guédron, S., Nguyen, N. S., Denis, H., \& Nguyen, P. D. (2017). Spatial variation and risk assessment of trace metals in water and sediment of the Mekong Delta. Chemosphere, 179 (March), 367 - 378 . https://doi.org/10.1016/j.chemosphere.2017.03.105.

Tao, Y., Yuan, Z., Xiaona, H., \& Wei, M. (2012). Distribution and bioaccumulation of heavy metals in aquatic organisms of different trophic levels and potential health risk assessment from Taihu Lake, China. Ecotoxicology and Environmental
Safety, 81, 55-64. http s://doi.org/10.1016/j. ecoenv.2012.04.014.

Tarique, Q., Burger, J., \& Reinfelder, J. R. (2012). Metal concentrations in organs of the clam Amiantis umbonella and their use in monitoring metal contamination of coastal sediments. Water, Air, and Soil Pollution, 223(5), 2125-2136. https://doi.org/10.1007/s11270-011-1009-0.

Thanh-Nho, N., Strady, E., Nhu-Trang, T., David, F., \& Marchand, C. (2018). Trace metals partitioning between particulate and dissolved phases along a tropical mangrove estuary (Can Gio, Vietnam). Chemosphere, 196, 311-322. https://doi.org/10.1016/j.chemosphere.2017.12.189.

Tong, P. H. S., \& Nguyen, T. T. (2011). The relationship between natural conditions and the formation and development of clam grounds (Meretrix lyrata) in the mekong delta. In M. A. Stewart \& P. A. Coclanis (Eds.), Environmental change and agricultural sustainability in the mekong delta (Vol. 45, pp. 303-333). Springer Netherlands. https://doi.org/10.1007 1978-94-007-0934-8_18.

Truong, Q. P. (2000). Biological and bio-chemical characteristics of Meretrix lyrata (Sowerby) and the high productivity hard clams farming methods. Nha Trang University, Nha Trang.

Tu, N. P. C., Ha, N. N., Agusa, T., Ikemoto, T., Tuyen, B. C., Tanabe, S., \& Takeuchi, I. (2010). Concentrations of trace elements in Meretrix spp. (Mollusca: Bivalva) along the coasts of Vietnam. Fisheries Science, 76(4), 677-686. https://doi.org/10.1007/s12562-010-0251-5.

Tuyet, T. N. N., Némery, J., Gratiot, N., Strady, E., Viet, Q. T., \& An, T. N. (2019). Nutrient dynamics and eutrophication assessment in the tropical river system of Saigon - Dongnai (southern Vietnam). Science of the Total Environment, 653, 370-383. https://doi.org/10.1016/j.scitotenv.2018.10.319.

U.S. EPA (1991a). Nickel, soluble salts. https://www.epa.gov/iris

U.S. EPA (1991b). Selenium and compounds. https://www.epa. gov/iris

U.S. EPA (1995). Manganese. https://www.epa.gov/iris

U.S. EPA (2005). Human health risk assessment protocol for hazardous waste combustion facilities (Vol. EPA530-R-0). EPA530-R-05-006

U.S. EPA (2011). Exposure Factors Handbook 2011 Edition (Final Report). Washington, DC. https://cfpub.epa. gov/ncea/risk/recordisplay.cfm?deid $=236252$

van Duijn, A.P., Betkers, R., van der Pji, W. (2012). The Vietnamese seafood sector - a value chain analysis. Compiled for CBI by LEI, Part of Wageningen UR.

Vo, P. L. (2007). Urbanization and water management in Ho Chi Minh City, Vietnam-issues, challenges and perspectives. GeoJournal, 70(1), 75-89. https://doi.org/10.1007/s10708008-9115-2.

Vodopivez, C., Curtosi, A., Villaamil, E., Smichowski, P., Pelletier, E., \& Mac Cormack, W. P. (2015). Heavy metals in sediments and soft tissues of the Antarctic clam Laternula elliptica: more evidence as a ? Possible biomonitor of coastal marine pollution at high latitudes? Science of the Total Environment, 502(October 2014), 375-384. https://doi. org/10.1016/j.scitotenv.2014.09.031.

Walpole, S. C., Prieto-Merino, D., Edwards, P., Cleland, J., Stevens, G., \& Roberts, I. (2012). The weight of nations: an estimation of adult human biomass. BMC Public Health, 12(1), 439. https://doi.org/10.1186/1471-2458-12-439. 
Wong, K. W., Yap, C. K., Nulit, R., Hamzah, M. S., Chen, S. K., Cheng, W. H., Karami, A., \& al-Shami, S. A. (2016). Effects of anthropogenic activities on the heavy metal levels in the clams and sediments in a tropical river. Environmental Science and Pollution Research, 24(1), 116-134. https://doi.org/10.1007/s11356-016-7951-Z.

Wu, H., Ji, C., Wang, Q., Liu, X., Zhao, J., \& Feng, J. (2013). Manila clam Venerupis philippinarum as a biomonitor to metal pollution. Chinese Journal of Oceanology and Limnology, 31(1), 65-74. https://doi.org/10.1007/s00343013-2037-y.

Wu, X., Xiao, S., Li, X., Li, L., Shi, W., \& Yu, Z. (2014). Evolution of the tRNA gene family in mitochondrial genomes of five Meretrix clams (Bivalvia, Veneridae). Gene, 533(1), 439-446. https://doi.org/10.1016/j. gene.2013.09.077.

Yap, C. K., Edward, F. B., \& Tan, S. G. (2014). Concentrations of heavy metals in different tissues of the bivalve Polymesoda erosa: its potentials as a biomonitor and food safety concern. Pertanika Journal of Tropical Agricultural Science, 37(1), 19-38.

Publisher's note Springer Nature remains neutral with regard to jurisdictional claims in published maps and institutional affiliations. 